University of Massachusetts Amherst

ScholarWorks@UMass Amherst

Afro-American Studies Faculty Publication Series

Afro-American Studies

2003

\title{
"Pat Your Foot and Turn the Corner": Amiri Baraka, the Black Arts Movement, and the Poetics of a Popular Avant-Garde
}

James E. Smethurst

University of Massachusetts - Amherst, jsmethur@afroam.umass.edu

Follow this and additional works at: https://scholarworks.umass.edu/afroam_faculty_pubs

\section{Recommended Citation}

Smethurst, James E., "'Pat Your Foot and Turn the Corner": Amiri Baraka, the Black Arts Movement, and the Poetics of a Popular Avant-Garde" (2003). African American Review. 60.

$10.2307 / 1512312$

This Article is brought to you for free and open access by the Afro-American Studies at ScholarWorks@UMass Amherst. It has been accepted for inclusion in Afro-American Studies Faculty Publication Series by an authorized administrator of ScholarWorks@UMass Amherst. For more information, please contact scholarworks@library.umass.edu. 


\section{"Pat Your Foot and Turn the Corner": Amiri Baraka, the Black Arts Movement, and the Poetics of a Popular Avant-Garde}

$\mathrm{M}$ y larger objective here is to engage the current cultural conversation about the nature of the Black Arts Movement and its impact on politics and culture in the United States and beyond. So while I honor the significance of Amiri Baraka's work as artist, critic, and activist, my intention is to place that work within a movement in which Baraka is but one voice among many, albeit an important one. In other words, in the spirit of Baraka's own critical and autobiographical writings, I want to emphasize, to the degree that it is possible in a short essay, the collectivity and diversity of the Black Arts Movement, and try to avoid the sort of great-man theory in which Baraka's work becomes a metonymy for all Black Arts literature, drama, criticism, and so on. ${ }^{1}$ I also want to say that this is a small part of a larger work-in-progress designed to further conversation rather than shut it off with some gesture toward authority.

As the term suggests, avant-garde connotes a bold journey into the future that, as Ezra Pound polemicized, made things new. This newness for many avant-gardists - say, the politically very different Mayakovsky and the Russian Futurists and Marinetti and the Italian Futurists (and much of the early William Carlos Williams, for that matter)-involved some vision of modernity which required the wholesale abandonment or even destruction of existing culture. To the degree that various avant-gardists sought or claimed inspiration from or kinship to existing (or once extant) cultures, these cultures tended to be somewhere else and/or to have existed at some other time. One thinks of Picasso and Africa, Artaud and Bali, Pound and Confucian China.

However, by the late 1960s a new conception of an avantgarde found its way into American culture. This was a paradoxical conception of the avant-garde that has roots in actually existing and close-to-home popular culture and is in some senses genuinely popular, while retaining a counter-cultural, alternative stance. This is a conception that is still with us now to a large extent. One has only to consider the many "alternative" radio stations which claim to be in the vanguard of the "rock revolution" to see not only the remarkable claim to avant-garde status by such major institutions of popular culture, but also that such a claim is both palatable and plausible to millions of listeners. To this one could add the phenomenon of "alt-country," which, though less high profile than "alternative rock," involves the sales of millions of CDs. And, in many respects, the almost clichéd hip hop obsession of "the real," with the term underground marking the hip hop artists and works that are most "real," expresses a similar concern with being popular, engaged, and yet formally challenging or new. ${ }^{2}$
James Smethurst is Assistant Professor of AfroAmerican Studies at the University of Massachusetts. His most recent book is The New Red Negro (Oxford UP, 1999). He is co-editor, with Bill V. Mullen, of Left of the Color Line: Race, Radicalism, and Twentieth-Century Literature of the United States (U of North Carolina P, 2003). 
This model of a popular avantgarde was significantly developed and promoted by the Black Arts Movement in the Northeast during the 1960s, in no small part through the efforts of the poet, playwright, essayist, cultural critic, and political activist Amiri Baraka, as well as in the work of Larry Neal, Askia Touré, James Stewart, and others. ${ }^{3}$ Black Arts participants synthesized and revised a cultural inheritance derived significantly from the Popular Front, using the "new thing" jazz or "free jazz" of the late 1950s and the 1960 s as a model for a popular avantgarde.

In one sense, the idea of a future society or culture rooted in some aspects of existing American culture and American realities, while simultaneously distinguishing itself from that culture, is quite old in the United States, dating back at least to Ralph Waldo Emerson. However, one significant import came to these shores in the late nineteenth and early twentieth centuries via the nationalist movements of the peoples of the internal colonies within the large empires of Europe: the Irish, the Finns, the Poles, the Czechs, the Hungarians, and so on. The artists associated with these nationalist movements often saw the peasant culture of their respective nationalities as containing the basis of a new national culture which could stand in opposition to imperial culture. However for these new cultures to be created, what was required was not the presentation or recreation of the peasant culture, but a transmutation of "folk" elements into a new "high" culture. In other words, Bartok, Janacek, and Sibelius did not by and large try to recreate or write music exactly in the spirit of Hungarian, Czech, or Finnish folk music, but to incorporate "folk" elements into their symphonies, string quartets, and so on.

This sort of cultural nationalism had considerable influence here in the United States. And possibly its most important impact here was on the artists and intellectuals of what became known as the New Negro Renaissance in the early twentieth century. The notion of transmuting folk materials into a new national or quasi-national culture was particularly influential on the older writers and intellectuals, such as James Weldon Johnson and Alain Locke, who were crucial in the organizing, promoting, and theorizing of a "Negro renaissance." ${ }^{4}$ This paradigm of the relation of the folk to a new "high" culture was very much couched in terms of generational conflict or difference, of old and new, of the genteel and the raw, of the formally timid and the formally adventurous - in short, the familiar rhetoric of the avant-garde.

One related, though somewhat opposed, aspect of the New Negro Renaissance was the attempt by some writers, notably Langston Hughes, Sterling Brown, Waring Cuney, and Helene Johnson, to create a new relationship between the folk and the modern African American writer. To put it very broadly, these writers tried to create a paradigm in which the folk or popular voice became the national voice, and the role of the poet in turn became service as a sort of oracle from whom the voice of the folk emerges rather than as a cultural alchemist transforming relatively base raw folk materials into high-culture gold a la Bartok, Synge, or Sibelius. Of course, this is a very broad characterization of that paradigm. On closer inspection, as many scholars have noted, these poets differed quite a bit. Brown in the early 1930s, for example, opposed "authentic" folk culture to "inauthentic" popular culture. Hughes tended to project a continuum between folk culture and popular culture, distinguishing instead between true and false popular culture usages of folk. Helene Johnson, drawing on the ambivalent and ambiguous forms of African American minstrelsy, blurred the line between folk and popular, between inauthentic and authentic in her most interesting poems, such as "Poem" ("Little brown boy, / Slim, dark, big-eyed, / Crooning love songs 
to your banjo / Down at the

Lafayette").

In some ways, these writers, notably Hughes and Brown, anticipated, influenced, and were influenced by the positions of the Communist Left that rose to a new prominence in the 1930s. Brown's position found a particular resonance in the early 1930 s when the Communist Left and the cultural institutions associated with it tended to promote the idea of an alternative worker or (in the case of African Americans) a national culture based in large part on residual folk practices that allegedly lay outside of popular commercial culture. ${ }^{5}$ In other words, what we see is the idea of a political avant-garde, or vanguard if you like, allegedly rooted in folk practices right here, right now, and yet still countercultural or alternative.

The other general theorization of the relation among a political vanguard, "high" culture, "folk" culture, and "popular" culture that emerged in the later 1930s via the Communist Left is associated with the Popular Front, which was an extremely complex and far-reaching social formation, even in the area of expressive culture. ${ }^{6}$ For the purposes of this essay, the Popular Front's most important aspect is the approach to mass culture it generally promoted: Instead of being a form of thought control, popular culture was a field of contestation in which "progressive" artists could battle fascism and what Franklin Delano Roosevelt called the "economic royalists." So even "high" artists who wrote novels or poems, composed "art" music, painted pictures, and so on, would infuse their work with the themes, cadences, imagery, and media of mass culture. The artists who took this approach for the most part did not see themselves as simply using popular culture, but often celebrated what they saw as its progressive aspects, which expressed the American democratic spirit. Perhaps the most notable example of this approach is found in the work of Langston Hughes during the 1930s and 1940s (and beyond). For instance, Hughes began publishing his "Simple" stories, focusing on the life of an "average" Harlemite, Jesse B. Semple, in early 1943 as a part of his widely syndicated "Here to Yonder" column in the Chicago Defender. Not only do these stories celebrate African American popular culture (as well as such white popular artists as Bing Crosby) and incorporate black music, vaudeville comedy routines, various "folk" practices (e.g., the dozens), and a huge range of literary, musical, folkloric, sociological, political, and historical allusions into the formal structure of the stories themselves, but the stories were in fact popular culture productions in that they were written for the mass circulation African American press.

This raises one of the most notable, and most noted, features of Popular Front aesthetics: a cultural intermixing of highbrow and lowbrow (and even the dreaded "middlebrow"), of pulp and high modernism, of folk culture and mass culture, of different genres, of different media. It was the blurring of boundaries of media, genre, aesthetics, and even audience that in no small part was the focus of ultimately successful assaults by the New Critics and the Partisan Review circle on Popular Front poetics - at least in academia - though, as Michael Denning has argued, Popular Front poetics remained influential on mass culture even as the Communist Left was increasingly isolated during the Cold War era. Other examples of this intermixing include Hughes's popular 1938 "poetry-play" Don't You Want to Be Free, in which Hughes's poems were interspersed among blues and gospel songs; singer/guitarist Josh White's and poet Waring Cuney's collaboration on the LP record Southern Exposure; Woody Guthrie's song "Tom Joad" (which compressed Steinbeck's Grapes of Wrath into a seven-minute ballad set to the tune of "Black Jack Davey" and was issued on a RCA Victor 78-rpm record); Muriel Rukeyser's poetic 
sequence "Book of the Dead," which was filled with fragments of "non-literary" documents such as government records, court testimony, diary entries, and stock exchange listings; and Richard Wright's blues "King Joe" (a minor jukebox hit in 1941, set to music by Count Basie and recorded by the Basie Orchestra with Paul Robeson singing - and Jimmy Rushing coaching Robeson on how to sing the blues). Another important of feature of much Popular Front art is an interest in race and ethnicity and the relation of racial identity and ethnic identity to an American identity. This aspect of the Popular Front has often been misunderstood in that Popular Front constructs of "the people" have been set in opposition to particularized ethnic or racial identity. However, when one considers the poetry of Sterling Brown, Don West, Aaron Kramer, Frank Marshall Davis, Langston Hughes, Waring Cuney, and Margaret Walker; narratives such as Pietro di Donato's Christ in Concrete, Jerre Mangione's Mount Allegro, Daniel Fuchs's Low Company, Carlos Bulosan's America Is in the Heart, H. T. Tsiang's And China Has Hands, and Richard Wright's Native Son; the famous "Spirituals to Swing" concerts of 1939; and paintings by Jacob Lawrence, Ben Shahn, Aaron Douglas, John Biggers, Charles White, and Jack Levine, to name but a few of many examples, it is clear that race and ethnicity remain overriding concerns during the Popular Front, albeit concerns which are as much about transformation as they are tradition.

Finally, many of the artistic, literary, or quasi-literary works of the Popular Front are marked by an interest in place and its relation to American identity, an interest that is often closely connected to the above- mentioned concern with race and ethnicity. While the place represented, recreated, and dissected is most commonly a specific urban neighborhood-Harlem, Brooklyn's Williamsburg, Chicago's South Side, Detroit's Paradise Valley, New York's Chinatown, Boston's West End, and so on-such representations are frequently rural, as in Meridel LeSueur's portrait of the upper Midwest in North Star Country and Don West's poems of the Southern mountains. Examples of this focus on place are legion-Woody

Guthrie's Dust Bowl Ballads, Josh White and Waring Cuney's recorded collaboration Southern Exposure, the already noted work of such writers as Mangione, Hughes, Brown, Le Sueur, di Donato, Walker, West, Fuchs, and Wright, and, perhaps most famously, the products of the WPA, notably the Federal Writers Project American Guide Series and the photographs taken under the auspices of the Farm Security Administration.

The Communist Left in both its political and cultural forms was severely damaged, isolated, and driven under cover during the Cold War. In many ways, the inheritors of these Left traditions of the relation among popular culture, high culture, and an oppositional avant-garde were the largely literary movements associated with the Beats, the New York School, the Black Mountain School, and the California Renaissance. Quite a few of the artists most prominently associated with these schools (particularly the older "patrons" of the new literary avantgarde)-Charles Olson, Allen Ginsberg, Stuart Perkoff, Bob Kaufman, Kenneth Rexroth, Lawrence Lipton, and Frank O'Hara, among others-had some sympathy for and/or association with Popular Front politics. 
This loosely connected avant-garde inherited from the Popular Front interests in place, ethnicity and race, sometimes history, and particularly the themes and forms of popular culture. It was this fascination with popular culture and a willingness to draw on the resources of popular culture that in no small part distinguished most of the varieties of the literary counterculture from the so-called "academic" poetssay, Robert Lowell, John Berryman, and Delmore Schwartz.

A particular touchstone of this counterculture was jazz, particularly bebop, and its association with African American culture. In this, as with many earlier avant-gardes, these writers (the white ones, anyway) could be accused of the old "someone else, somewhere else, some other time" romanticism. However, it is worth noting that many of these writers' works featured prominently other sorts of popular culture forms and icons: the Shadow, the Green Hornet, Jayne Mansfield, James Dean, Lana Turner, and so on. Nonetheless, despite this interest in popular culture that they represented as more generally American and less specifically "other," these writers, unlike the Popular Front artists who preceded them and the Black Arts participants who followed them, represented themselves as a permanently small, embattled subculture for the most part. In fact, one of the main distinctions between the early works of the different "schools" can be found in the manner in which they represented their alienation. The Beats were often by turns pessimistic, prophetic, and humorously satiric and self-satiric; the Black Mountain School, especially Charles Olson, as Frank $\mathrm{O}^{\prime}$ Hara noted, were highly (and perhaps overly) conscious of the Pound heritage of finding the great statement; and the New York poets, especially Frank O'Hara, Kenneth Koch, and James Schuyler, made this alienation seem fun and playful, for the most part.
A mong the participants of the literary counterculture of the 1950 s and early 1960 s were a number of black artists and intellectuals who would be crucial to the development of the Black Arts Movement, notably Amiri Baraka. Baraka, as is well known, was a vital member of this counterculture of the 1950s and 1960s as a leading writer, organizer, editor, publisher, and cultural critic. Baraka, as the editor of the journals Yugen and The Floating Bear and the publisher of Totem-Corinth books, played a huge role in creating the idea of a New American Poetry comprised of these fairly disparate "schools" - thereby preparing the way for the conception and reception of Donald Allen's landmark anthology of the counterculture, The New American Poetry (1960). Fairly early in his participation in this literary bohemia, Baraka began to theorize a continuum of African American folk culture, African American popular culture, the semi-avant-garde of bebop, and the "free jazz" of such musicians as Ornette Coleman, John Coltrane, Cecil Taylor, and Sun Ra. In his 1963 cultural history of jazz and the blues, Blues People, Baraka wrote of the new jazz avant-gardists:

What these musicians have done, basi-
cally, is to restore to jazz its valid sepa-
ration from, and anarchic disregard of,
Western popular forms. They have
used the music of the forties, with its
jagged, exciting rhythms, as an initial
reference and have restored the hege-
mony of the blues as the most impor-
tant basic form in Afro-American
music. (225)

It is important to note here that Baraka is claiming, much as Hughes did before him, a cultural continuum stretching from the earliest worksongs and hollers through the blues, early jazz, bebop, and rhythm and blues to the certifiably "out there" sounds of Cecil Taylor and Ornette Coleman. He is arguing that, rather than being a cultural alchemist, a cultural archivist, a cultural imperialist, or a cultural mimic, the jazz avant-garde at its best engages in a conversation with Son House, Duke Ellington, Thelonious 
Monk, Ray Charles, Muddy Waters, and Mahalia Jackson. I say at its best because contained in Blues People is a kernel of the proscriptive aspect of Baraka's later Black Arts work in which he polemicizes against jazz musicians relying too heavily on the European art music tradition (or the "mainstream" pop tradition) at the expense of blues and rhythm \& blues. Thus, Baraka was able to take the Beat notion of African Americans as a class of permanent non-conformists (or involuntary saints) - who are nonetheless quintessentially American - and locate himself inside it without the sort of primitivist mysticism that often attended Beat expressions of this idea (as in Jack Kerouac's portrait of Mardou Fox in The Subterraneans). This tendency can be seen most clearly in the 1962 essay "City of Harlem":

\begin{abstract}
Harlem for this reason is a community of nonconformists, since any black American, simply by virtue of his blackness, is weird, a nonconformist in this society. A community of non-conformists, not an artists' colonythough blind "ministers" still wander sometimes along $137^{\text {th }}$ Street, whispering along the strings of their guitarsbut a colony of old-line americans, who can hold out, even if it is a great deal of the time in misery and ignorance, but still hold out, against the hypocrisy and sterility of big-time America. (Home 93)
\end{abstract}

Later, Baraka would take his proscriptive notion of a cultural continuum to a much higher pitch, so to speak, as the most famous participant of the Black Arts Movement. ${ }^{7}$ This notion is articulated most famously his essay "The Changing Same" (1967), a work that has given its title as an almost ubiquitous shorthand for the essential continuity of African American expressive culture:

That what will come will be a Unity Music. The Black Music which is jazz and blues, religious and secular. Which is New Thing and Rhythm and Blues. The consciousness of social reevaluation and rise, a social spiritualism. A mystical walk up the street to a new neighborhood where all the risen will live. (Jones/Baraka Reader 210)
To continue the music analogy, this was a note that was not simply struck by Baraka, but one sounded over and over by such Black Arts participants as Askia Touré, Sonia Sanchez, Jayne Cortez, Larry Neal, A. B. Spellman, critic Stephen Henderson, James Stewart, and Ishmael Reed. Touré was particularly important in theorizing the notion of African American popular music as a part of the Black Arts upsurge and the necessity for serious black revolutionary artists to engage $r \& b$ and other forms of black popular culture. Though less well known now than "The Changing Same," Touré's "Keep On Pushin': Rhythm \& Blues as a Weapon" (1965) anticipated many of Baraka's points - and Baraka's prophetic voice:

Somewhere along the line, the "Keep
On Pushin" " in song, in Rhythm and
Blues is merging with the
Revolutionary Dynamism of
COLTRANE of ERIC DOLPHY of
BROTHER MALCOLM of YOUNG
BLACK GUERILLAS STRIKING DEEP
INTO THE HEARTLAND OF THE
WESTERN EMPIRE. (450)

As Mike Sell points out, another crucial, though almost completely unstudied, point of development and transmission of this idea, both influencing and influenced by Baraka, Touré, and other New York-based activists, was the Muntu circle of Philadelphia (57-59). This group was a crucial incubator of Black Arts poetics and artists, including Larry Neal, painter/musician James Stewart, and playwright Charles Fuller. Stewart's essay "The

Development of the Revolutionary Black Artist" (first published in Black Dialogue in 1966) is the opening piece of the seminal 1968 Black Fire anthology edited by Baraka and Neal. Though Stewart's vision of the continuity of African American culture was more folkloric and more broadly diasporic and less engaged with popular music than Neal's and Baraka's, nonetheless he also posited the notion of a black avant-garde rooted in contemporary 
African American artistic/spiritual practices:

We need our own conventions, a convention of procedural elements, a kind of stylization, a sort of insistency which leads inevitably to a certain kind of methodology - a methodology affirmed by the spirit.

That spirit is black.

That spirit is non-white.

That spirit is patois.

That spirit is Samba.

Voodoo.

The black Baptist church in the South. (6)

Some of the most important articulators of this idea of a cultural continuum were the musicians themselves.

One can see this in Ornette Coleman's persistent emphasis on his early training as a rhythm and blues musician in Texas and in Cecil Taylor's claim in A. B. Spellman's Four Lives in the Bebop Business (1966) that, despite the tendency of white critics to associate him with such white European and American avant-gardists as Karlheinz Stockhausen and John Cage, he plays "an extension of period musicEllington and Monk" (29). Perhaps the most striking statement of this notion of continuum was in the actual performance of Sun Ra and his Arkestra, where African-style chants and instrumentation merged with Fletcher Henderson, doo wop, bebop, electronic music, and "free" improvisation, often culminating in "When the Saints Go Marching In." ${ }^{8}$ It is worth noting that this framing of "free jazz" by the musicians, a number of whom had ambivalent relationships to the Black Arts Movement, was given voice and ideological consistency and elaboration in the critical and belletristic writings of such Black Arts activists as Baraka, Touré, Sonia Sanchez, Neal, and Spellman. In other words, it was most often in such works as Spellman's Four Lives and Baraka's Black Music (1968), as well as in uncollected essays by Touré, Neal, Baraka, Spellman, and others in such periodicals as Journal of Black Poetry, The Liberator, Kulchur, and The Cricket (a Black Arts music journal edited by Baraka, Neal, and Spellman and oriented mostly toward the new jazz, but which nonetheless featured such $\mathrm{r} \& \mathrm{~b}$ artists as Stevie Wonder and Otis Redding on its cover) that these comments by the musicians were given public voice and contextualized.

Never before could one find such a large, relatively cohesive, and heavily theorized American avant-garde which so emphatically linked its radical formal and ideological practices to popular culture with the notion that this counterculture would be all - at least as far as the African American community was concerned. This is not to say that this paradigm did not empower a variety of formal and thematic results on the part of Black Arts poets. As Amiri Baraka and Lorenzo Thomas have noted, in some poets, notably Askia Touré (who was an $\mathrm{r} \& \mathrm{~b}$ singer as a young man), the formal rhythms and performative styles were significantly rooted in gospel and $r$ \& b song as well as in "new thing" jazz. In other cases, particularly those of Larry Neal and Yusef Rahman, a sort of bop sensibility predominated. ${ }^{9}$

Baraka himself drew on both strains in his work. To get a sense of the impact of Touré, Rahman, and Neal on Baraka's performative style, it is instructive to listen to the Baraka's reading of "Black Dada Nihilismus" on the LP New York Art Quartet, recorded in November 1964, and compare it to his reading of "Black Art" on Sonny's Time Now, recorded almost exactly one year later. Obviously, both readings are engaged with "new thing" jazz, featuring some of leading "free jazz" players of the era, including Sonny Murray, Albert Ayler, Don Cherry, Milford Graves, Roswell Rudd, Lewis Worrell, and John Tschai-and both mark Baraka's political transition to a militant nationalism. However, the latter reading is clearly more directly influenced by gospel and $\mathbf{r} \& \mathrm{~b}$ song. Baraka's later style, also significantly marked by the scatting and onomatopoetic sounds of the Chicago poet Amus Mor, in turn became a founda- 
tion for the performance styles of a wide range of Black Arts poets. ${ }^{10}$ However, again, these shared or synthesized strategies worked out quite differently in the work of different poets. For example, Touré drew on vernacular black music to create an epic tone in much of his work, whereas Baraka and Sanchez, like Langston Hughes before them, invoke and utilize much the same resources while remaining in a basically lyric mode, even in such epic efforts as Baraka's recent Wise, Why's, Y's (1995) - as Langston Hughes did in Montage of a Dream Deferred and Ask Your Mama.

One enormous impact of the Black Arts Movement is the obvious influence it exercised on the conceptions of racial, ethnic, national, gender, and sexual identity in the United States and what might be thought of as movement poetics - whether this influence came through inspiration by Black Arts or reaction against it (or both). While the movement awaits full scholarly treatment, it can still inspire considerable passion, as seen in Jerry Watts's new study of Baraka, which is a sort of polemic against Baraka and Black Arts, and in the lionization of Baraka, Nikki Giovanni, Sonia Sanchez, and the Last Poets on Russell Simmons's four-part Def Poetry spoken-word series hosted by rapper Mos Def on HBO.

\section{$\mathrm{H}$} aving noted some of the direct, continuing influences of Black Arts, as a sort of coda, I'm going to mention one aspect of Black Arts influence that might use some more attention as an example of how the movement fundamentally transformed the way art is received and understood in the United States through the notion of a popular avant-garde that drew its inspiration in large part from a model of the relation between iconic "free jazz" artists and popular artists of rhythm and blues and earlier jazz.

"Free jazz" artists had an iconic status for many rock and $r \& b$ artists as well as for Black Arts participants. As Kalamu ya Salaam points out, one thinks of James Brown's call to "blow me some Trane, brother," on the hit single "Super Bad." Perhaps Brown liked Coltrane. Perhaps he was paying tribute to a band member, Robert "Chopper" McCollough, who, like many $r$ \& b instrumentalists, had another musical life as a jazz player. ${ }^{11}$ However, Brown is also trying to publicly link his own music with an icon of the African American avant-garde, suggesting a basic connection or kinship. ${ }^{12}$ There is also the example of the first Byrds album, where the liner notes mention that one band member likes to play John Coltrane riffs on the mandolin and that another "worships" Coltrane's drummer Elvin Jones. This may have been true, or not, but the question is why mention it at all except, again, to invoke Coltrane as an icon of a new sort of avant-garde. A similar sort of worship can be found in the name of Rob Tyner, the lead singer of the MC5, a radical Detroit rock band which covered a Sun Ra tune on its first album. Tyner apparently took his last name from McCoy Tyner, the pianist of the classic Coltrane groups (Sinclair interview). One can find many other examples, especially in album liner notes and in interviews with leading popular musicians during the 1960 s and early 1970 s, similar claims to musical and spiritual kinship to Coltrane, Coleman, Albert Ayler, Sun $\mathrm{Ra}$, and other leading "free jazz" artists.

In part, these rock and $\mathrm{r} \& \mathrm{~b}$ musicians were drawn to "free jazz" by the new chordal, rhythmic, and tonal approaches of such musicians as Coleman and Coltrane, an attraction which would dramatically change the character of rock performance, in which the ability to perform in a relatively free improvisational style became a marker of artistic sophistication. (And, in turn, jazz musicians such as Miles Davis and, especially, alumni of Davis's bands, including Wayne Shorter, Herbie Hancock, Tony 
Williams, and John McLaughlin, would draw on the drive and popular appeal of rock and $r \& b$ as well as the jazz avant-garde to create early "fusion.") But beyond that technical musical appeal, the model of an avant-garde art that is both "cutting edge" thematically and formally and yet rooted in popular culture, which itself is a sort of popular culture, is something that comes in no small part from this model that used the "new thing" jazz artists and found its most powerful and developed articulation within the Black Arts Movement.

As a result, the position of many segments of the U.S. population (and those beyond the United States) now vis-à-vis popular culture and what is valuable, authentic, real, oppositional, cutting-edge, underground, and so on, and what is not, is vastly different from what would have been the case before the Black Arts Movement. This is not to say that the promotion of such a model through popular culture is the "real" contribution of the Black Arts Movement. Rather my point here is that the work of Amiri Baraka and other Black Arts activists, rather than being short-lived in influence and ultimately peripheral to the main cultural arenas of the United States, as some still charge, fundamentally changed the conception of art and culture in the United States, both inside and outside the African American communityoften in ways that have received little or no commentary inside and outside academia.

1. For an important recent study which promotes a sort of inverse great-man theory in order to attack both Baraka and the Black Arts Movement, see Watts.

2. My term popular avant-garde is clearly influenced by Werner Sollors's notion of "Baraka's persistent demand for a populist modernism, a unity of life and art, literature and society" (8), though my genealogy and application of the term differs from that of Sollors (and the early Baraka). I am similarly indebted to William Harris's formulation of Baraka's "jazz aesthetic," though again my sense of the ancestry of Baraka's poetics as traced through the New American Poetry "schools" of the 1950s and 1960 s and its link to popular culture differs somewhat from Harris's-at least as expressed in The Poetry and Poetics of Amiri Baraka.

3. The stance of the Black Arts Movement elsewhere, though influenced by the movement in the Northeast, was quite different. For example, the early movement in Chicago, especially among writers, was much closer to a more traditional notion of an avant-garde or vanguard which viewed popular culture with some suspicion, if not outright hostility. On the other hand, the notion of a popular avant-garde greatly influenced the artists of BLKARTSOUTH in New Orleans, as Kalamu ya Salaam notes in the poem "Food for Thought," where he proclaims "ameer baraka (leroi jones) the 'bird' of blk poetics" (379). However, the New Orleans poets and theater workers took this model and used it (and the vital New Orleans jazz and $r$ \& b scene of the time) to validate the worth of their own efforts in the South against what they saw as Northern neglect or condescension (Dent 335; Salaam, "BLKARTSOUTH/get on up!" 469).

4. Locke's most famous invocation of an African American transposition of European nationalism can be found in the opening essay of The New Negro (1925): "Without pretense to their political significance, Harlem has the same role to play for the New Negro as Dublin has for the New Ireland or Prague for the New Czechoslovakia" (7). A similar sentiment can be found in James Weldon Johnson's Preface to the first edition of The Book of American Negro Poetry (1922), in which he declares that "what the colored poet in the United States needs to do is something like Synge did for the Irish" (41).

5. For an early articulation of this position by Brown himself, see Brown, "The Blues as Folk Poetry."

6. For a sense of the range of the forms and influence of the Popular Front in American culture, see Denning. For a sense of the impact of the Popular Front on African American politics and culture, see Mullen.

7. The directly proscriptive spirit of the essay comes mostly in quick asides-for example, "the black artist is most often always hip to European art, often at his jeopardy" (197).

8. For a brief description of a typical Sun Ra performance (and its relation to Black Arts theory), see Thomas, “Classical Jazz” 239. 
9. Baraka, Autobiography (236-37); Baraka interview; Thomas, Extraordinary Measures 130-31; Thomas, "Communicating By Horns" 295-97; Spellman interview; Touré interview.

10. Baraka, Autobiography 237; Baraka interview.

11. ya Salaam, Magic of Juju 193-94. As Suzanne Smith notes, many members of the Motown studio band were also jazz players (159-61).

12. It is also worth noting that the favor was returned, since Brown's approach to rhythm, melody, and chord changes influenced the new jazz, especially after the mid-1960s. As drummer Beaver Harris said, “James Brown recorded this tune and I remember him saying, 'Give the drummer some!' That opened a lot of eyes and ears" (Wilmer 155).

Works Baraka, Amiri (LeRoi Jones). The Autobiography of LeRoi Jones. New York: Freundlich, 1984.

Cited -. Black Music. New York: Morrow, 1968.

-. Blues People. New York: Morrow, 1963.

-. The Dead Lecturer. New York: Grove P, 1964.

-. Home: Social Essays. New York: Morrow, 1966.

-. Interview with James Smethurst. 15 July 2000. Newark, NJ.

-. The LeRoi Jones/Amiri Baraka Reader. New York: Thunder's Mouth P, 1991.

Brown, Sterling A. "The Blues as Folk Poetry." Folk-Say, A Regional Miscellany: 1930. Ed. Benjamin

A. Botkin. Norman: U of Oklahoma P, 1931. 324-39.

Denning, Michael. The Cultural Front. New York: Verso, 1997.

Dent, Tom. "Enriching the Paper Trail: An Interview with Tom Dent." African American Review 27 (1993): 327-44.

Harris, William J. The Poetry and Poetics of Amiri Baraka: The Jazz Aesthetic. Columbia: U of Missouri P, 1985.

Johnson, James Weldon, ed. The Book of American Negro Poetry. New York: Harcourt, 1922.

Locke, Alain, ed. The New Negro: An Interpretation. New York: Boni, 1925.

Mullen, Bill V. Popular Fronts: Chicago and African-American Cultural Politics, 1935-1946. Urbana: U of Illinois P, 1999.

Sell, Mike. "The Black Arts Movement: Performance, Neo-Orality, and the Destruction of the "White Thing.' " African American Performance and Theater History: A Critical Reader. Ed. Harry J. Elam, Jr., and David Krasner. New York: Oxford UP, 2001. 56-80.

Sinclair, John. Interview with James Smethurst. 11 Oct. 2001. Cambridge, MA.

Smith, Suzanne. Dancing in the Street: Motown and the Cultural Politics of Detroit. Cambridge: Harvard UP, 1999.

Sollors, Werner. Amiri Baraka/LeRoi Jones: The Quest for a "Popular Modernism". New York: Columbia UP, 1978.

Spellman, A. B. Black Music: Four Lives. 1966. New York: Schocken, 1970.

-. Interview with James Smethurst. 28 Dec. 2000. Washington, DC.

Stewart, James T. "The Development of the Black Revolutionary Artist." Black Fire: An Anthology of Afro-American Writing. Ed. LeRoi Jones and Larry Neal. New York: Morrow, 1968. 3-10.

Thomas, Lorenzo. "Classical Jazz and the Black Arts Movement." African American Review 29 (1995): $237-40$.

—. "'Communicating by Horns': Jazz and Redemption in the Poetry of the Beats and the Black Arts Movement." African American Review 26 (1992): 291-98.

-. Extraordinary Measures: Afrocentric Modernism and Twentieth-Century American Poetry. Tuscaloosa: U of Alabama P, 2000.

Touré, Askia (Rolland Snellings). "The Crisis in Black Culture." Journal of Black Poetry 1.8 (1968): 2 10.

-. Interview with James Smethurst. 2 Dec. 2000. Cambridge, MA.

—. "Keep On Pushin': Rhythm \& Blues as a Weapon." 1965. Black Nationalism in America. Ed. John Bracey, Jr., August Meier, and Elliot Rudwick. Indianapolis: Bobbs-Merrill, 1970. 445-51.

Watts, Jerry Gafio. Amiri Baraka: The Politics and Art of a Black Intellectual. New York: New York UP, 2001.

Wilmer, Valerie. As Serious As Your Life: The Story of the New Jazz. 1977. Westport: Lawrence Hill, 1980.

ya Salaam, Kalamu. "BLKARTSOUTH/get on up!" New Black Voices. Ed. Abraham Chapman. New York: Mentor, 1972. 468-73.

—. "Food for Thought." New Black Voices. Ed. Abraham Chapman. New York: Mentor, 1972. 378-79.

-. The Magic of Juju: An Appreciation of the Black Arts Movement. Chicago: Third World P, forthcoming. 